\title{
Talking with Children About Cancer: A Content Analysis of Text in Children's Picture Books
}

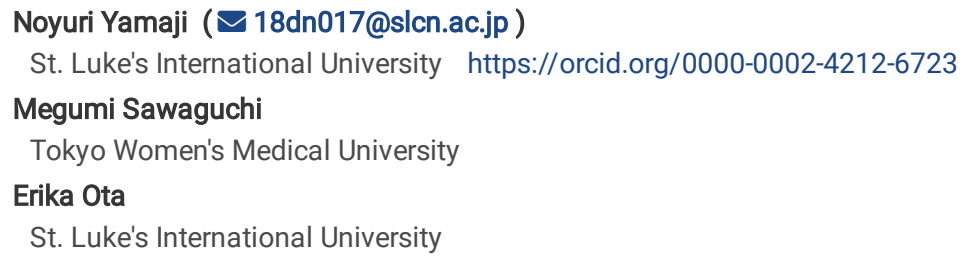

Version of Record: A version of this preprint was published at Health on January 1st, 2020. See the published version at https://doi.org/10.4236/health.2020.127055. 


\section{Abstract \\ Background}

To tell children that they are diagnosed with cancer is challenging for any healthcare professional and family. Pictures books are one of the communication tools for talking with children about severe diseases. However, little research is available about the contents and appropriateness of picture books about cancer for children.

\section{Methods}

This study aimed to examine the contents of children's picture books about cancer and explore the advantages and disadvantages of using picture books to communicate with children about cancer. We searched the picture books about cancer written for children aged under ten years old on the Amazon.com Web site on 5 July 2019 and hand-searched on the cancer-related institutes' Web site. We extracted the texts of relevant picture books and conducted a contents analysis of them. Two researchers independently coded the patterns and contents and calculated the agreement between the codings of two researchers using Cohen's kappa coefficient.

\section{Results}

We identified 2,555 picture books and included 30 of them. We identified three main contents, (a) cancer-related knowledge, (b) impacts of cancer, and (c) dealing with cancer. Cancer-related knowledge refers to the information about what is going on and what children have to do. Impacts of cancer refer to the impact of having a child with cancer. Dealing with cancer relates to the actions to reduce or minimize stressful events that had been described. These contents were written with simple words and illustrations. Some of them included the essential contents, which might be misunderstood by children.

\section{Conclusions}

Picture books use plain language with illustrations and might be helpful for children to understand about cancer. However, as these books do not include all contents, it is necessary to select and use multiple books depending on the content which is wanted to tell the child. Moreover, there was no picture book which was developed based on children's information needs and validated. Further research should evaluate the impacts of these books as a communication tool when talking with children diagnosed with cancer.

\section{Background}

Among the most common illnesses is cancer in the world, and approximately 300,000 children and teens under the age of 19 are diagnosed with cancer every year [1]. One of the hardest challenges for any healthcare professional (HCP) and family is to tell children that they have a life-threatening disease. Previous studies have been showed that talking with children about their illnesses reduces their anxiety and depression [2]. Conversely, if children received no information or lack of information about illnesses, they experienced negative emotions because of the illness uncertainty [3]. Some children experience childhood cancer to be stressful and traumatic [4,5]. While benefits of talking about illnesses have been known, there are little specific evidence-based guidelines about how to talk about life-threatening illnesses directly with children [6]. Although children want medical information to be provided by HCPs or parents[7, 8], they tend to avoid sensitive communication with the chilren. HCPs and families need specific strategies for talking to children about cancer.

One of the specific tools to communicate with children are books. Books have been recognized to help children deal with severe problems [9], and shared reading has significant influences on educational and health outcomes [10,11]. The books can be chosen based on children's developmental stages and understanding. Huang, Lee, Hu, Gao, \& O'Connor (2015) analyzed text in picture books about mother's breast cancer [12]. However, there was no studies that examined picture books written for children who are diagnosed with cancer. It is not yet clear what the contents of these books include, nor whether they match the information that the children want to know.

\section{Methods}

\section{Aims}

This study aimed to examine the contents of these children's books and summarize the perspectives related to telling children about cancer. Also, we explored the possibilities of using picture books to communicate with children about cancer when they are diagnosed with cancer.

\section{Study Design And Procedure}

We conducted a qualitative study. Data were obstain from a systematic review and we used qualitative content analysis of the text from childrens picture books about cancer. Content analysis is a research method whereby researchers can quantify and analyze the words and concepts from a variety of communicative languages such as books, book chapters, essays, interviews, discussions, and articles [13]. We used content analysis because it is most 
appropriate in examining the contents of a particular body of materials through identifying patterns, contents, or bias from narrative data particularly when there is little research on the topic [14].

\section{Books Selection And Analysis}

Picture books were selected based on the following criteria: (1) written for children under ten years old, (2) focusing on the contents of cancer such as disease, mechanism, treatment, social experiences, and daily life, (3) written in English or Japanese. Even though the picture books were not written about cancer directly, we included them if the cancer-related institutions recommended it. Picture books which focused on death and family members' diagnosis were excluded.

The first author selected the picture books that the American Childhood Cancer Organization, Yale Cancer Center, Live Better With Cancer, Ehime prefectural library, and other institutions related to childhood cancer that recommended books for children with cancer under the age of 10 . To find relevant picture books, the first author also searched the websites of Amazon Japan (https://www.amazon.co.jp/) using the keyword "cancer" after focusing on children's books in foreign books.

The first author extracted all texts of relevant picture books and written on word file. Two researchers independently coded the patterns and contents of all the material. Following the selection of articles, two researchers lumped into sub-contents, then categorized the contents. Agreement between the coding of two researchers was calculated using Cohen's kappa coefficient. We assessed agreement values $0-0.20$ as none to slight, $0.21-0.40$ as fair, $0.41-0.60$ as moderate, $0.61-0.80$ as substantial, and $0.81-1.00$ as almost perfect agreement [15] (Table 2).

\section{Results}

The picture books were searched on 5 July 2019 and identified were 2,555 potentially relevant picture books using Amazon's internal search engine and manual searching; 2,509 books were excluded based on titles and abstract reviews. Of the remaining 46 full-text books, 16 were eliminated because of different inclusion criteria. Finally, 30 picture books that met the inclusion criteria were selected (Fig. 1) [16-45]. The picture books included in this study were published from 1988 to 2018 in the United States of America, the United Kingdom, Japan, and Canada. Most of these picture books were written based on the experiences of children diagnosed with cancer, or on information about cancer. HCPs were involved in the development of some picture books. However, there were none based on the survey results for children and families. Most of the picture books directly described the experience with the protagonist's cancer, and two tried to explain cancer through another story such as an analogy [26, 30]. For example, one book showed cancer as a distinctive flower among the flowers that bloom in the garden. Another book showed cancer as a journey to cure the disease. Some books, which were recommended by cancer-related institutes focused on feelings, not cancer. Word counts ranged from 177 to 2,030 words, and there were more than 5,457 characters in two Japanese picture books $[16,45]$. This value corresponded to approximately 2,729 to 3,410 words in English. While the range of reading level was one year and up, some books had no maximum age limit. Some of them did not correlate reading level with the number of pages and words. We summarized the characteristics of the included picture books in Table 1. The main contents of these picture books were identified as (a) cancer-related knowledge, (b) impacts of cancer, and (c) dealing with cancer (Table 2).

\section{Cancer-related Knowledge}

Cancer-related knowledge refers to the information about what is going on and what children have to do, including "basic information about cancer" (agreement: substantial), "examinations/procedures" (agreement: substantial), and "treatments" (agreement: moderate).

\section{Basic Information}

While some books focused on specific cancer types such as leukaemia and brain tumours, most books focused on the generic term of cancer. They explained that there were many different kinds of cancer. In many books, cancer was generally interpreted as an illness that turned healthy cells into abnormal cells, and the body could not function because they were proliferating. Some books described that cancer was not contagious, and no one knew what causes cancer. It emphasized and explained that it is not caused by their behaviour, thinking, or what they said.

"Mom always knows what I'm thinking. "No one is sure why you have cancer, Clara," she says. "But we do know that it isn't because of anything you did, or thought, or said." "Thank goodness!" I smile. ([34], p. 11)

Symptoms caused by cancer, such as feeling sick, sleepy, and tired, were described in many books. In most books, symptoms were emerged within the story about the main character who had been diagnosed with cancer, and later recovered from cancer after treatments. A few books mentioned a recurrence of cancer.

\section{Examinations/ Procedures}

Many picture books covered the examinations and procedures such as blood tests, vital sign measurements, bone marrow aspiration, and x-ray. These were described to allay the reader's fear, for example, that anaesthesia could be taken before undergoing invasive procedures and it makes them fall asleep.

\section{Treatments}


In most books, chemotherapy was described as an effective treatment that could help eliminate cancer cells. Moreover, side effects such as hair loss, fatigue, nausea, and bone marrow suppression were described. Some books dealt with the main topic of hair loss, indicating that patients spent time wearing hats or wig during treatments, and their hair grew back eventually.

\section{Impacts Of Cancer}

The impact of cancer refers to the impact of having a child with cancer, including their "daily life" (agreement: moderate), "children's emotions" (agreement: substantial), and "parent's emotions" (agreement: almost perfect agreement).

\section{Daily Life}

In most books, it was brought up that after the diagnosis of cancer the child's daily life had changed from normal. Hospitalization was often explained. Children's negative and positive emotions were both described. For example, hospitalization separated them from family members and friends, and so they felt alone and sad.

\section{Children's Emotions}

There were descriptions of various types of feelings, such as being sad, scared, angry, embarrassed, and alone. The books described what kind of atmosphere there was for each situation. In the picture story books, emotions were described as the main characters' emotions with a short description of why they felt that way. After they were diagnosed with cancer, they felt sad because they saw their parents cry. They felt scared when they took the treatments, examinations, and procedures. Also, they felt angry and expressed that it was unfair.

"Ally got mad at the cancer. She said, "That is not fair! I do not want to be tired. I want to run and play again. How do we fight the cancer? How do we make it go away?"([26], p. 15)

They felt embarrassed of the change in body image when their hair fell out.

"Her hair fell out and when it was gone, her head was white as snow. At first, she felt embarrassed, and sometimes had to cry." ([24], ).

On the other hand, there were a few descriptions of positive emotions such as being happy and amazed when they played with their friends; when they reconfirmed their love; when they went back home, and when they recovered from cancer. Some books emphasized that it was normal to have many feelings and that they could tell someone anything.

"I have so many feelings. I don't know what to do. But I don't have to feel guilty or ashamed about my feelings. They are a part of me. And it's okay to let my feelings out." ([22], p. 13-15)

\section{Parents' Emotions}

Some picture books described parent's feelings, such as being sad and anxious when their children were diagnosed with cancer. Also, how they were deeply moved when their children recovered from cancer.

\section{Dealing With Cancer}

Dealing with cancer refers to the actions to reduce or minimize stressful events that had been described, including "children's coping strategies" (agreement: almost perfect agreement), message for readers (agreement: almost perfect agreement), and "social support" (agreement: substantial).

\section{Children's Coping Strategies}

The main characters who were diagnosed with cancer tried to cope with the stressful events that they had to do but did not want to do and about which they had negative feelings. For children, stressors varied, such as cancer, treatments, procedures, hair loss, and hospitalization. Also, there were a variety of children's coping strategies, including emotion-focused coping, which changed their emotional response to the stressor. Another one was problem-focused coping, where they directly approached to the problem. They had a way of coping with stressful events by changing their minds and taking other actions.

"I may lose all of my hair but I hope to win life. Cancer will be beaten. Captain Chemo is on my side." ([35], p. 5-6)

\section{Message for Readers}

At the end of the story, it was emphasized that the main character was a valuable person and should be loved by others, even if they were diagnosed with cancer..

"The truth about cancer is... It does not define who you are or who you will be. You and only you get to write your story." ([42], p. 22)

\section{Social Support}

The main characters were supported by their family members, HCPs, teachers, and friends. They realized that they were not alone and that they were fighting against cancer together. Most of the picture books that mentioned family referred to the parents; few books referred to siblings.

Page $4 / 13$ 
"Since kicking cancer is hard work for our whole family. Mom and Dad make sure we still do a lot of fun things together. It's great to know I don't need to kick cancer all on my own." ([17], p. 24)

\section{Discussion}

The study systematically identified picture books about cancer and coded the contents. The results of this study could contribute to a concrete way to communicate with children about cancer.

\section{Advantages Of Picture Books}

Being open and honest when talking about cancer has been widely expanded [46]. Likewise, early palliative care, including communication with the patients about the illness and its prognosis, symptom assessment and management, support for coping, and regular follow-ups have been found to improve the quality of life [47]. Some studies suggest that reading and using picture books before procedures promote children's understanding and reduce stress [48] and anxiety [49]. Picture books about cancer could be used to communicate about cancer with children. These might also help children understand not only cancer but also their daily lives more deeply, thereby alleviating their concerns. The contents, "cancer-related knowledge", and "impacts of cancer" are helpful to children's understanding. Because most picture books were written using simple words with illustrations to explain that it is possible to treat cancer and be cured of it, Jalmsell et al. (2016) suggested that children with cancer desire be given accurate information as positively as possible to preserve hope [8]. The content of "dealing with cancer" might support children to express their emotions and cope with cancer through the main character's emotions or learning directly from the books. Indeed, some picture books include meaningful sentences that can correct children's common misunderstandings. For example, children sometimes think the cause of cancer is their fault. Some picture books explain that their illness is not their fault.

\section{Disadvantages Of Picture Books}

A similar study that analyzed 45 picture books about maternal breast cancer assessed all the books to be beneficial to children and adults. However, some contents such as school life and financial burdens, and instructions about age-appropriateness were not enough [12]. Likewise, this study indicated that the picture books written about cancer for children were lacking similar information. Although cancer-related institutes and Amazon described the ageappropriateness, some picture books have too many words and are challenging to understand for children of the target age. Sharing information with them should be according to their developmental stages [50]. The minimum target age for children to read and understand should be clarified. Although, siblings need the information to understand the situation that their sibling has cancer [51], there are few books, which include them in the stories.

Katz, \& Webb, (2016) asserted that children's involvement in the discussion of their medical condition be part of standard patient care. However, this practice is yet to be widespread and there is a lack of evidence-based specific guides on how to tell children about cancer considering children's developmental stages and emotions [6,52]. Picture books might be helpful as a communication tool about cancer, even though the contents of these books are different from each other. Thus, the book chosen should be based on its relevance to the child's particular medical condition.

\section{Implications For Practice And Future Research}

Disclosure has been asserted to be a child's right [53,54], and many studies have shown that open communication is beneficial to keep good relationships with children [55], and reduce children's stress [56]. However, disclosing a cancer diagnosis is sometimes challenging for HCPs and parents because there are some communication barriers, including lack of skills, and the preferences of parents [57]. By selecting and using a picture book that suits the purpose to inform, the picture books might help HCPs to communicate with children about cancer.

Further research should evaluate the impacts of these picture books for children with cancer, including using it as a communication tool. Additionally, there were no picture books listed based on surveys that were conducted to understand the preferences of children and families. The development of the materials, including a picture book to communicate with children, should be created based on children's and their family's information needs.

\section{Limitation}

There are some limitations to this study. First, we included only books that were searched on the Amazon Web site and some others recommended by a few cancer-related institutes. Further research should be conducted using several more comprehensive databases and keywords. Second, while pictures and drawings are essential for younger children, picture books that were selected for this study were evaluated using their texts. Younger children who do not have enough literacy to read the words can learn more by using functions other than reading. Although no method for synthesizing illustrations was available, further analysis of each picture book is necessary to include illustrations. Third, although, only the contents of these picture books were assessed. Future study should assess the effects of picture books, including the process of their actual use.

\section{Conclusion}

Picture books can be useful tools for HCPs and families as a communication tool for talking to children about cancer and can be helpful for children to understand and cope with cancer. However, it is necessary to select and use multiple books depending on the content. It should be noted that there was no 
picture book, which was evaluated for its validity and efficacy. Further research should assess the impacts of these books as a communication tool when talking with children diagnosed with cancer.

\section{Abbreviations}

$\mathrm{HCP}$

healthcare professional

\section{Declarations}

Acknowledgement

We would like to thank Sarah E Porter PhD RN, a native English speaker for providing English editing.

Funding

This work was supported by the Yasuda Medical Foundation.

Author information

Affliations

Department of Global Health Nursing, Graduate School of Nursing Science, St. Luke's International University, Tokyo, Japan

Noyuri Yamaji and Erika Ota

Department of Child Health Nursing, School of Nursing, Tokyo Women's Medical University, Tokyo, Japan

Megumi Sawaguchi

Authors' contributions

NY involved in the conception and design, screening of relevant picture books, analysis of the texts, and drafting the manuscript. MS involved in the blinded analysis of the data, and revising this manuscript. EO involved in the conception and design and revising this manuscript. All authors gave their final approval of this version to be published.

Corresponding author

Correspondence to Noyuri Yamaji

Ethics declarations

Ethics approval and consent to participate

Not applicable.

Consent for publication

Not applicable.

Availability of data and materials

The datasets used and/or analysed during the current study are available from the corresponding author on reasonable request.

Competing interests

The authors declare that they have no competing interests.

\section{References}

1. International Agency for Research on Cancer: International Childhood Cancer Day: Much remains to be done to fight childhood cancer. In.; 2016. https://www.iarc.fr/en/media-centre/pr/2016/pdfs/pr241_E.pdf. (Accessed at 20200528).

2. Adduci A, Jankovic M, Strazzer S, Massimino M, Clerici C, Poggi G. Parent-child communication and psychological adjustment in children with a brain tumor. Pediatric blood cancer. 2012;59(2):290-4.

3. Fortier MA, Batista ML, Wahi A, Kain A, Strom S, Sender LS: Illness uncertainty and quality of life in children with cancer. Journal of pediatric hematology/oncology 2013, 35(5):366-370. 
4. Taieb O, Moro MR, Baubet T, Revah-Levy A, Flament MF. Posttraumatic stress symptoms after childhood cancer. Eur Child Adolesc Psychiatry. 2003;12(6):255-64.

5. Rodriguez EM, Dunn MJ, Zuckerman T, Vannatta K, Gerhardt CA, Compas BE. Cancer-related sources of stress for children with cancer and their parents. J Pediatr Psychol. 2012;37(2):185-97.

6. Stein A, Dalton L, Rapa E, Bluebond-Langner M, Hanington L, Stein KF, Ziebland S, Rochat T, Harrop E, Kelly B, et al. Communication with children and adolescents about the diagnosis of their own life-threatening condition. The Lancet. 2019;393(10176):1150-63.

7. Brand SR, Fasciano K, Mack JW. Communication preferences of pediatric cancer patients: talking about prognosis and their future life. Supportive care in cancer: official journal of the Multinational Association of Supportive Care in Cancer. 2017;25(3):769-74.

8. Jalmsell L, Lövgren M, Kreicbergs U, Henter J-I, Frost B-M. Children with cancer share their views: tell the truth but leave room for hope. Acta Paediatr. 2016;105(9):1094-9.

9. Cohen LJ. Bibliotherapy: Using literature to help children deal with difficult problems. J Psychosoc Nurs Ment Health Serv. 1987;25(10):20-4.

10. Lonigan CJ, Shanahan T. Executive Summary Developing Early Literacy: Report of the National Early Literacy Panel A Scientific Synthesis of Early Literacy Development and Implications for InterventionExecutive Summary of the report of the national early literacy panel.; 2008.

11. Niklas F, Schneider W. Intervention in the home literacy environment and kindergarten children's vocabulary and phonological awareness. First Language. 2017;37(5):433-52.

12. Huang X, Lee S, Hu Y, Gao H, O'Connor M. Talking About Maternal Breast Cancer With Young Children: A Content Analysis of Text in Children's Books. J Pediatr Psychol. 2015;40(6):609-21.

13. Mike A. The SAGE Encyclopedia of Communication Research Methods. 2017.

14. Leedy PD, Ormrod JE. Practical research: Planning and design: Upper Saddle River. N.J: Prentice Hall.; 2005.

15. Cohen J. A coefficient of agreement for nominal scales. Educ Psychol Meas. 1960;20(1):37-46.

16. Bergman T: Children fighting with cancer - Live a full day a day (in Japanese): Kaisei Sya; 1989.

17. Billups EA: The Puddle Jumper's Guide to Kicking Cancer: Puddle Jumper Books; 2017.

18. Brent M, Knutsson C: Chemo to the Rescue USA: Author House; 2008.

19. Carney KL: Together, We'll Get Through This!: Dragonfly Pub; 1998.

20. Dawson M: The Cancer Answer Kid (Sophia): A book about pediatric cancer: The Cancer Answer Kid (sophia); 2013.

21. Demaio K. Big Charles: Fighting Cancer With Courage: eLive Audio Download Included. USA: Tate Pub \& Enterprises LIc; 2014.

22. American Cancer Society

My Cancer Day

Filigenzi C, Tadgell N. My Cancer Day: American Cancer Society; 2016.

23. Fisher J, Huie C: I'm a kid living with cancer: Wine Pr Pub; 2010.

24. Fox D, Lew B. Amazing Annabelle: A story for Kids Fighting Cancer. USA: Small But Mighty Books; 2017.

25. Gaynor K: The Famous Hat: Special Stories Publishing; 2008.

26. Gullia C: Doctor, what is Cancer?: Friesen Press; 2017.

27. Hoard G. Emily has cancer: AuthorHouse; 2019.

28. Marvelous Marleigh

Hoffman RI. M-D. V: Marvelous Marleigh: American childhood Cancer Organization; 2015.

29. Karst P, Stevenson G: The Invisible String. Devorss \& Co; 2000.

30. Leonard AV, Fox TP. The Hare Who Lost Her Hair Createspace Independent Pub; 2013.

31. Moss MA. God, Are You. There?: Davand Publishing; 2016.

32. Parr T: The Feelings Book: Little, Brown Books for Young Readers; 2005.

33. Reynolds C, Wright SA, Smith D, R. JL: The Guardian Angel volume 1: RJ helps a child with Cancer: RRJ Publishing INC; 2017.

34. Robert M, Ely K. SuperClara: A Young Girl's Story of Cancer. Bravery: Dreamchaser Publishing; 2018.

35. Robinson R. Captain chemo!: The Phoenix Winter; 2012.

36. Romain T: Lift Me Up: The Candlelighters Childhood Cancer Foundation; 2008.

37. Schmidt C: What is Cancer?: A Book for Kids: CreateSpace Independent Publishing Platform; 1988.

38. Snow T, Snow P: Feelings to Share: Maren Green Pub Inc; 2007.

39. Snow T, Snow P, Espeland P. C. H: Feelings to Share from A. to Z: Maren Green Pub; 2007.

40. Snyder B, Engelsgjerd M: What Every Child Needs To Know About Cancer: Need To Know; 2014.

41. Spicer AV. A CANCER LIFE; 2018.

42. Strenge K: The Truth About Cancer: Includes Elive Audio Download: Tate Pub \& Enterprises LIc; 2015.

43. Tillman N: Wherever You Are: My Love Will Find You: Feiwel \& Friends; 2010.

44. Van J. SuperVan Tackles Cancer Tackles Cancer 2017.

Page $7 / 13$ 
45. Watanabe, Arata. Let's know about your childhood leukemia (in Japanese): Nanzando; 2002.

46. Sisk BA, Bluebond-Langner M, Wiener L, Mack J, Wolfe J. Prognostic Disclosures to Children: A Historical Perspective. Pediatrics 2016, 138(3).

47. Haun MW, Estel S, Rucker G, Friederich HC, Villalobos M, Thomas M, Hartmann M. Early palliative care for adults with advanced cancer. Cochrane Database Syst Rev. 2017;6:Cd011129.

48. Tsao Y, Kuo HC, Lee HC, Yiin SJ. Developing a medical picture book for reducing venipuncture distress in preschool-aged children. International journal of nursing practice $2017,23(5)$.

49. Nilsson E, Svensson G, Frisman GH. Picture book support for preparing children ahead of and during day surgery. Nursing children young people. 2016;28(8):30-5.

50. Piaget J. Part I: Cognitive development in children: Piaget development and learning. Journal of Research in Science Teaching. 1964;2(3):176-86.

51. Sloper P. Experiences and support needs of siblings of children with cancer. Health Social Care in the Community. 2000;8(5):298-306.

52. Katz AL, Webb SA. Informed Consent in Decision-Making in Pediatric Practice. Pediatrics 2016, 138(2).

53. Daugherty CK, Hlubocky FJ. What are terminally ill cancer patients told about their expected deaths? A study of cancer physicians' self-reports of prognosis disclosure. Journal of clinical oncology: official journal of the American Society of Clinical Oncology. 2008;26(36):5988-93.

54. Hudson N, Spriggs M, Gillam L. Telling the truth to young children: Ethical reasons for information disclosure in paediatrics. J Paediatr Child Health. 2019;55(1):13-7.

55. Mack JW, Wolfe J, Cook EF, Grier HE, Cleary PD, Weeks JC. Peace of mind and sense of purpose as core existential issues among parents of children with cancer. Arch Pediatr Adolesc Med. 2009;163(6):519-24.

56. Rosenberg AR, Dussel V, Kang T, Geyer JR, Gerhardt CA, Feudtner C, Wolfe J. Psychological distress in parents of children with advanced cancer. JAMA pediatrics. 2013;167(6):537-43.

57. Sisk BA, Mack JW, Ashworth R, DuBois J. Communication in pediatric oncology: State of the field and research agenda. Pediatric blood cancer. 2018;65(1):e26727.

\section{Tables}

Table 1: Characteristics of Included Picture Books 


\begin{tabular}{|c|c|c|c|c|c|c|c|}
\hline Authors, Year & $\begin{array}{l}\text { Grade } \\
\text { level } \\
\text { (years) }\end{array}$ & Country & Topic & $\begin{array}{l}\text { Main } \\
\text { character }\end{array}$ & $\begin{array}{l}\text { Paperback } \\
\text { (Pages) }\end{array}$ & $\begin{array}{l}\text { Word count } \\
\text { of main text }\end{array}$ & $\begin{array}{l}\text { Kindle } \\
\text { version } \\
\text { available }\end{array}$ \\
\hline Bergman, 1989 [16] & $6-12$ & Japan & Basic information on cancer & $\begin{array}{l}\text { Children } \\
\text { with } \\
\text { cancer }\end{array}$ & 47 & $7491 *$ & N/A \\
\hline Billups, 2017 [17] & 0 and up & USA & Experience of cancer & $\begin{array}{l}\text { Child with } \\
\text { cancer }\end{array}$ & 36 & 1148 & $x$ \\
\hline $\begin{array}{l}\text { Brent \& Knutsson, } 2008 \\
\text { [18] }\end{array}$ & $6-8$ & USA & Basic information on leukemia & $\begin{array}{l}\text { Child with } \\
\text { cancer }\end{array}$ & 48 & 1260 & N/A \\
\hline Carney, 1998 [19] & $4-8$ & USA & Coping & Animal & 32 & 1236 & N/A \\
\hline Dawson, 2013 [20] & 2 and up & USA & Basic information on cancer & $\begin{array}{l}\text { Child with } \\
\text { cancer }\end{array}$ & 26 & 441 & $x$ \\
\hline Demaio, 2014 [21] & $4-8$ & USA & Basic information on cancer & $\begin{array}{l}\text { Child with } \\
\text { cancer }\end{array}$ & 32 & 624 & $\mathrm{~N} / \mathrm{A}$ \\
\hline $\begin{array}{l}\text { Filigenzi \& Tadgell, } 2016 \\
\text { [22] }\end{array}$ & $7-9$ & USA & Experience of cancer & $\begin{array}{l}\text { Child with } \\
\text { cancer }\end{array}$ & 16 & 292 & $\mathrm{~N} / \mathrm{A}$ \\
\hline Fisher \& Huie, 2010 [23] & 4 and up & USA & Experience of cancer & $\begin{array}{l}\text { Child with } \\
\text { cancer }\end{array}$ & 32 & 1045 & $\mathrm{~N} / \mathrm{A}$ \\
\hline Fox \& Lew, 2017 [24] & 0 and up & USA & $\begin{array}{l}\text { Basic information on cancer \& } \\
\text { fighting against cancer }\end{array}$ & $\begin{array}{l}\text { Child with } \\
\text { cancer }\end{array}$ & 19 & 808 & $x$ \\
\hline Gaynor, 2008 [25] & $6-8$ & UK & Experience of cancer & $\begin{array}{l}\text { Child with } \\
\text { cancer }\end{array}$ & 30 & 695 & $x$ \\
\hline Gullia, 2017 [26] & 0 and up & Canada & Basic information on cancer & Animal & 28 & 739 & $x$ \\
\hline Hoard, 2019 [27] & $4-10$ & UK & Experience of cancer & $\begin{array}{l}\text { Child with } \\
\text { cancer }\end{array}$ & 12 & 254 & $x$ \\
\hline Hoffman \& M-D., 2015 [28] & $1-5$ & USA & Experience of cancer & $\begin{array}{l}\text { Child with } \\
\text { cancer }\end{array}$ & 31 & 337 & N/A \\
\hline $\begin{array}{l}\text { Karst \& Stevenson, } 2000 \\
\text { [29] }\end{array}$ & $4-8$ & USA & Coping & $\begin{array}{l}\text { Children } \\
\text { and } \\
\text { mother }\end{array}$ & 36 & 511 & $x$ \\
\hline Leonard \& Fox, 2013 [30] & $4-8$ & USA & Basic information on cancer & Animal & 32 & 870 & N/A \\
\hline Moss, 2016 [31] & 2 and up & USA & Experience of cancer & $\begin{array}{l}\text { Child with } \\
\text { cancer }\end{array}$ & 34 & 523 & $x$ \\
\hline Parr, 2005 [32] & $0-3$ & Canada & Coping & No setting & 24 & 177 & N/A \\
\hline $\begin{array}{l}\text { Reynolds, Wright, Smith, \& } \\
\text { Jacson, 2017 [33] }\end{array}$ & 1 and up & USA & Experience of cancer & $\begin{array}{l}\text { Child with } \\
\text { cancer }\end{array}$ & 35 & 2030 & $x$ \\
\hline Robert \& Ely, 2018 [34] & 0 and up & USA & Experience of cancer & $\begin{array}{l}\text { Child with } \\
\text { cancer }\end{array}$ & 34 & 1141 & $x$ \\
\hline Robinson, 2012 [35] & 3 and up & $\mathrm{N} / \mathrm{A}$ & $\begin{array}{l}\text { Basic information on } \\
\text { chemotherapy }\end{array}$ & $\begin{array}{l}\text { Fancy } \\
\text { characters }\end{array}$ & 44 & 197 & $x$ \\
\hline Romain, 2008 [36] & $3-10$ & USA & Coping & Animals & 22 & 212 & $\mathrm{~N} / \mathrm{A}$ \\
\hline Schmidt, 1988 [37] & 4 and up & $\mathrm{N} / \mathrm{A}$ & Basic information on cancer & $\begin{array}{l}\text { Child with } \\
\text { cancer }\end{array}$ & 25 & 798 & $x$ \\
\hline Snow \& Snow, 2007 [38] & $1-3$ & USA & Coping & No setting & 22 & 180 & $\mathrm{~N} / \mathrm{A}$ \\
\hline $\begin{array}{l}\text { Snow, Snow, Espeland, } \\
\text { Hartman, } 2007 \text { [39] }\end{array}$ & 3 and up & USA & Coping & No setting & 30 & 967 & $\mathrm{~N} / \mathrm{A}$ \\
\hline $\begin{array}{l}\text { Snyder \& Engelsgjerd, } 2014 \\
\text { [40] }\end{array}$ & $6-8$ & USA & Basic information on cancer & No setting & 22 & 365 & $x$ \\
\hline Spicer, 2018 [41] & $\begin{array}{l}\text { Children } \\
\text { to adults }\end{array}$ & USA & Experience of cancer & $\begin{array}{l}\text { Child with } \\
\text { cancer }\end{array}$ & 17 & 544 & $x$ \\
\hline Strenge, 2015 [42] & $4-8$ & USA & Basic information on cancer & $\begin{array}{l}\text { Child with } \\
\text { cancer }\end{array}$ & 30 & 347 & $\mathrm{~N} / \mathrm{A}$ \\
\hline Tillman, 2010 [43] & $4-8$ & USA & Coping & Child & 32 & 265 & $x$ \\
\hline
\end{tabular}




\begin{tabular}{|c|c|c|c|c|c|c|c|}
\hline Authors, Year & $\begin{array}{l}\text { Grade } \\
\text { level } \\
\text { (years) }\end{array}$ & Country & Topic & $\begin{array}{l}\text { Main } \\
\text { character }\end{array}$ & $\begin{array}{l}\text { Paperback } \\
\text { (Pages) }\end{array}$ & $\begin{array}{l}\text { Word count } \\
\text { of main text }\end{array}$ & $\begin{array}{l}\text { Kindle } \\
\text { version } \\
\text { available }\end{array}$ \\
\hline Van, 2017 [44] & 3 and up & & Experience of cancer & $\begin{array}{l}\text { Child with } \\
\text { cancer }\end{array}$ & 24 & 370 & $x$ \\
\hline Watanabe, 2002 [45] & $4-12$ & Japan & Basic information on leukemia & No setting & 28 & $5457^{*}$ & N/A \\
\hline
\end{tabular}

Table 2: Main Contents of Picture Books about Cancer 


\begin{tabular}{|c|c|c|c|c|c|c|c|c|c|}
\hline \multirow[b]{2}{*}{$\begin{array}{l}\text { Authors, } \\
\text { Year }\end{array}$} & \multicolumn{3}{|c|}{ Cancer-Related Knowledge } & \multicolumn{3}{|c|}{ Impacts of Cancer } & \multicolumn{3}{|c|}{ Dealing with Cancer } \\
\hline & $\begin{array}{l}\text { Basic } \\
\text { Information }\end{array}$ & Examinations/Procedures & Treatments & $\begin{array}{l}\text { Daily } \\
\text { Life }\end{array}$ & $\begin{array}{l}\text { Children's } \\
\text { Emotions }\end{array}$ & $\begin{array}{l}\text { Parent's } \\
\text { Emotions }\end{array}$ & $\begin{array}{l}\text { Children's } \\
\text { Coping } \\
\text { Strategies }\end{array}$ & $\begin{array}{l}\text { Message } \\
\text { for } \\
\text { Readers }\end{array}$ & $\begin{array}{l}\text { Social } \\
\text { Support }\end{array}$ \\
\hline $\begin{array}{l}\text { Bergman, } \\
1989 \text { [16] }\end{array}$ & $x$ & $x$ & $x$ & $x$ & $x$ & $x$ & & & $x$ \\
\hline $\begin{array}{l}\text { Billups, } \\
2017 \text { [17] }\end{array}$ & $x$ & $x$ & $x$ & $x$ & $x$ & $x$ & $x$ & & $x$ \\
\hline $\begin{array}{l}\text { Brent \& } \\
\text { Knutsson, } \\
2008 \text { [18] }\end{array}$ & $x$ & $x$ & $x$ & $x$ & & & $x$ & $x$ & $x$ \\
\hline $\begin{array}{l}\text { Carney, } \\
1998 \text { [19] }\end{array}$ & $x$ & & & $x$ & $x$ & & $x$ & & $x$ \\
\hline $\begin{array}{l}\text { Dawson, } \\
2013 \text { [20] }\end{array}$ & $x$ & $x$ & $x$ & $x$ & & & $x$ & & $x$ \\
\hline $\begin{array}{l}\text { Demaio, } \\
2014 \text { [21] }\end{array}$ & $x$ & & $x$ & $x$ & & & $x$ & $x$ & $x$ \\
\hline $\begin{array}{l}\text { Filigenzi \& } \\
\text { Tadgell, } \\
2016 \text { [22] }\end{array}$ & $x$ & & & $x$ & $x$ & & $x$ & & $x$ \\
\hline $\begin{array}{l}\text { Fisher \& } \\
\text { Huie, } 2010 \\
\text { [23] }\end{array}$ & $x$ & $x$ & $x$ & $x$ & $x$ & $x$ & $x$ & & $x$ \\
\hline $\begin{array}{l}\text { Fox \& Lew, } \\
2017 \text { [24] }\end{array}$ & $x$ & $x$ & $x$ & & $x$ & & $x$ & $x$ & $x$ \\
\hline $\begin{array}{l}\text { Gaynor, } \\
2008 \text { [25] }\end{array}$ & $x$ & & $x$ & $x$ & & & $x$ & $x$ & $x$ \\
\hline $\begin{array}{l}\text { Gullia, } 2017 \\
\text { [26] }\end{array}$ & $x$ & & $x$ & $x$ & $x$ & & $x$ & & $x$ \\
\hline $\begin{array}{l}\text { Hoard, } \\
2019 \text { [27] }\end{array}$ & & & & $x$ & $x$ & $x$ & $x$ & & $x$ \\
\hline $\begin{array}{l}\text { Hoffman \& } \\
\text { M-D., } 2015 \\
\text { [28] }\end{array}$ & $x$ & $x$ & $x$ & $x$ & & & $x$ & $x$ & $x$ \\
\hline $\begin{array}{l}\text { Karst \& } \\
\text { Stevenson, } \\
2000 \text { [29] }\end{array}$ & & & & & $x$ & & & & $x$ \\
\hline $\begin{array}{l}\text { Leonard \& } \\
\text { Fox, } 2013 \\
\text { [30] }\end{array}$ & $x$ & & $x$ & $x$ & $x$ & $x$ & $x$ & & $x$ \\
\hline $\begin{array}{l}\text { Moss, } 2016 \\
\text { [31] }\end{array}$ & $x$ & & & & $x$ & & $x$ & $x$ & $x$ \\
\hline $\begin{array}{l}\text { Parr, } 2005 \\
\text { [32] }\end{array}$ & & & & & & & $x$ & $x$ & \\
\hline $\begin{array}{l}\text { Reynolds, } \\
\text { Wright, } \\
\text { Smith, \& } \\
\text { Jacson, } \\
2017 \text { [33] }\end{array}$ & & & $x$ & $x$ & $x$ & & $x$ & & $x$ \\
\hline $\begin{array}{l}\text { Robert \& } \\
\text { Ely, } 2018 \\
\text { [34] }\end{array}$ & $x$ & & $x$ & $x$ & $x$ & & $x$ & $x$ & $x$ \\
\hline $\begin{array}{l}\text { Robinson, } \\
2012 \text { [35] }\end{array}$ & & & & & $x$ & & $x$ & $x$ & $x$ \\
\hline $\begin{array}{l}\text { Romain, } \\
2008 \text { [36] }\end{array}$ & & & & & $x$ & & $x$ & $x$ & $x$ \\
\hline $\begin{array}{l}\text { Schmidt, } \\
1988 \text { [37] }\end{array}$ & $x$ & & $x$ & & $x$ & & & & $x$ \\
\hline
\end{tabular}




\begin{tabular}{|c|c|c|c|c|c|c|c|c|c|}
\hline & \multicolumn{3}{|c|}{ Cancer-Related Knowledge } & \multicolumn{3}{|c|}{ Impacts of Cancer } & \multicolumn{3}{|c|}{ Dealing with Cancer } \\
\hline $\begin{array}{l}\text { Snow \& } \\
\text { Snow, } 2007 \\
\text { [38] }\end{array}$ & & & & & & & $x$ & & \\
\hline $\begin{array}{l}\text { Snow, } \\
\text { Snow, } \\
\text { Espeland, } \\
\text { Hartman } \\
2007 \text { [39] }\end{array}$ & & & & & & & $x$ & & \\
\hline $\begin{array}{l}\text { Snyder \& } \\
\text { Engelsgjerd, } \\
2014 \text { [40] }\end{array}$ & $x$ & & $x$ & & $x$ & & & $x$ & $x$ \\
\hline $\begin{array}{l}\text { Spicer, } \\
2018 \text { [41] }\end{array}$ & $x$ & $x$ & $x$ & $x$ & & & & $x$ & $x$ \\
\hline $\begin{array}{l}\text { Strenge, } \\
2015 \text { [42] }\end{array}$ & $x$ & & $x$ & & $x$ & & $x$ & $x$ & $x$ \\
\hline $\begin{array}{l}\text { Tillman, } \\
2010 \text { [43] }\end{array}$ & & & & & & & $x$ & $x$ & $x$ \\
\hline $\begin{array}{l}\operatorname{Van}, 2017 \\
{[44]}\end{array}$ & $x$ & $x$ & $x$ & & $x$ & & $x$ & & $x$ \\
\hline $\begin{array}{l}\text { Watanabe, } \\
2002[45]\end{array}$ & $x$ & $x$ & $x$ & & & & $x$ & $x$ & $x$ \\
\hline $\begin{array}{l}\text { Cohen's } \\
\text { Kappa }\end{array}$ & .66 & .66 & .49 & .48 & .65 & 1.0 & 1.0 & 1.0 & .66 \\
\hline
\end{tabular}

\section{Figures}




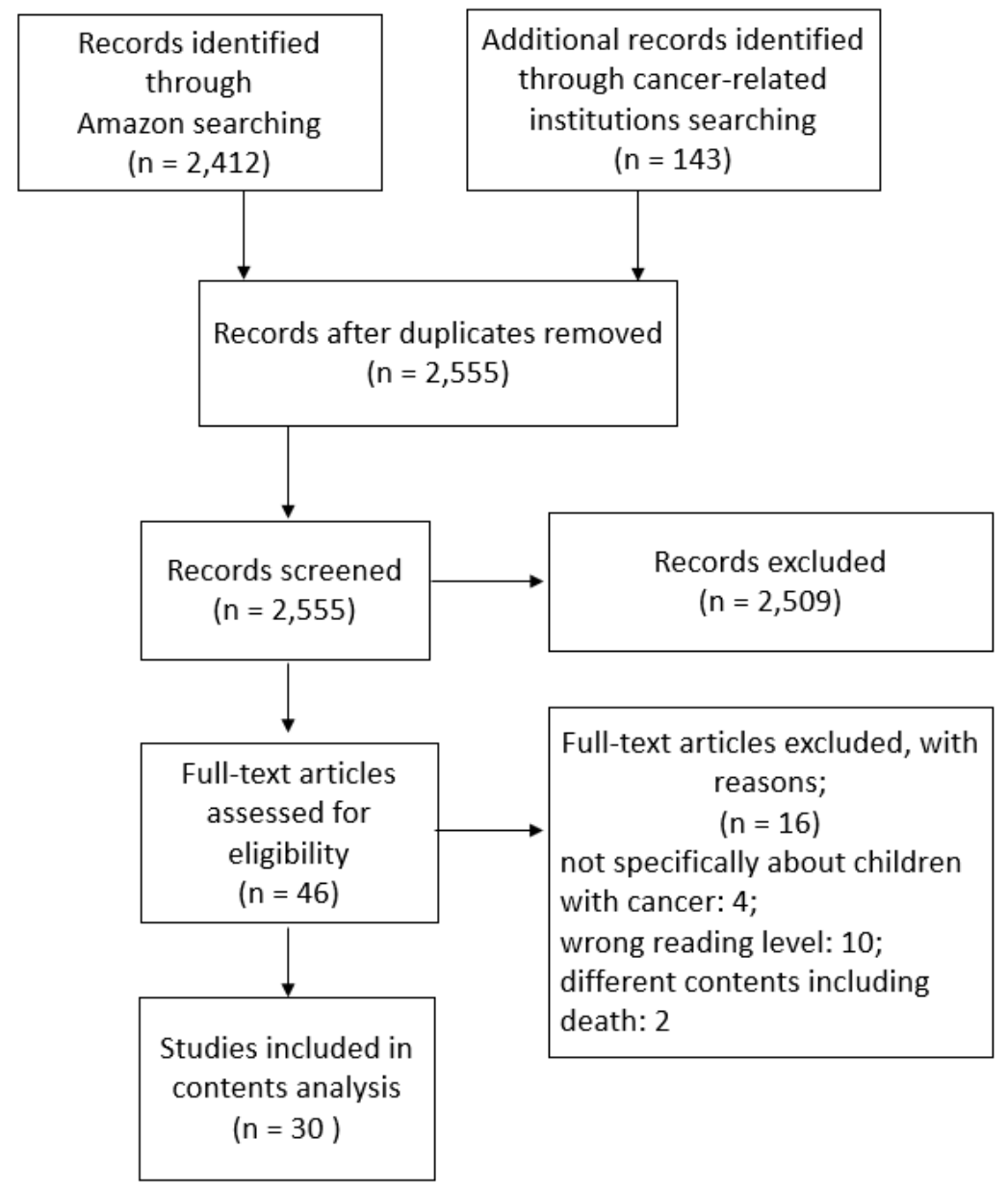

Figure 1

Process for the selection of picture books

\section{Supplementary Files}

This is a list of supplementary files associated with this preprint. Click to download.

- Contentsanalysisofpicturebook.PRISMA2009checklist.doc 